\title{
STATUS KESEHATAN IKAN LELE (Clarias gariepinus) YANG MENERIMA PAKAN BERSUPLEMEN KOMBINASI DAUN SIRIH (Piper betler leaf), JAMBU BIJI (Psidium guajava leaf), DAN KIPAHIT (Tithonia diversifolia leaf)
}

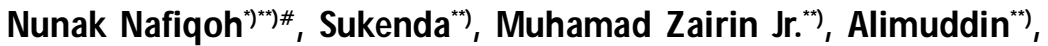 \\ Angela Mariana Lusiastuti*), dan Jean-Christophe Avarre ${ }^{* * *}$ \\ *) Balai Riset Perikanan Budidaya Air Tawar dan Penyuluhan Perikanan \\ Jl. Sempur No. 1, Bogor 16154 \\ *) Institut Pertanian Bogor \\ Jl. Agatis, Kampus Dramaga, Bogor, Jawa Barat 16680 \\ **) Institute Research and Development
}

(Naskah diterima: 8 Maret 2019; Revisi final: 1 April 2019; Disetujui publikasi: 1 April 2019)

\begin{abstract}
ABSTRAK
Tanaman obat telah banyak digunakan sebagai bahan pencegah dan pengobatan penyakit pada ikan budidaya. Penelitian ini ditujukan untuk mengetahui status kesehatan ikan lele (C. gariepinus) yang menerima pakan dengan suplemen tanaman obat kombinasi dari daun sirih, jambu biji, dan kipahit melalui pengamatan gambaran darah dan histologi ginjal sebagai organ yang memproduksi darah. Kombinasi satu merupakan kombinasi dari ketiga daun tanaman obat masing-masing sebanyak 33\% kombinasi dua juga terdiri dari daun sirih, jambu biji, dan kipahit masing-masing sebanyak 5\%19\%76\% dan kontrol yaitu pakan tanpa penambahan tanaman obat. Gambaran darah dan histologi ginjal diamati pada minggu ketiga setelah pemberian pakan. Hasil pengamatan gambaran darah menunjukkan bahwa terdapat peningkatan jumlah sel darah merah pada ikan yang menerima pakan perlakuan dibandingkan dengan kontrol $(0,4 \pm 0,14)$. Namun tidak terdapat perbedaan nyata antara jumlah sel darah merah dari kelompok perlakuan kombinasi satu dan dua $(1,5 \pm 0,17$ dan $1,4 \pm 0,1)$. Jumlah sel darah putih pada kelompok perlakuan juga meningkat dibandingkan dengan kelompok kontrol $(10,5 \pm 0,46)$, namun tidak terdapat perbedaan nyata antara kelompok perlakuan kombinasi satu dan dua $(15,1 \pm 1,19$ dan 17,6 \pm 1,14). Hasil pengamatan histologi terlihat jaringan hematopoietik organ ginjal dari kelompok yang menerima perlakuan berproliferasi lebih banyak dibandingkan kelompok kontrol. Namun tidak ada pengaruh pada nilai hemoglobin dan persentase leukosit diferensiasi antara kelompok perlakuan dan kontrol. Penambahan daun tanaman obat dalam pakan ikan mampu meningkakan status kesehatan dari ikan lele.
\end{abstract}

\section{KATA KUNCl: status kesehatan; Clarias gariepinus; pakan suplemen; Piper betle leaf; Psidium guajava leaf; Tithonia diversifolia leaf}

ABSTRACT: Improving health quality of catfish (Clarias griepenus) fed with combination of medicinal herbenriched diet. By: Nunak Nafiqoh, Sukenda, Muhamad Zairin Jr., Alimuddin, Angela Mariana Lusiastuti, and Jean-Christophe Avarre

\begin{abstract}
M edicinal herbs have been traditionally used as prophylactic and therapeutic supplement to treat diseases in aquaculture. This study was aimed to improve the health quality of catfish (C. gariepinus) through feeding on diets enriched with a combination of betel, guava, and tithonia as medicine by analyzing hematology and histology of kidney as blood producing organ. Diet-one was feed enrich with 33\% of each plant. Diet-two was feed enriched with betel, guava, and tithonia at a proportion of $5 \% 19 \%$ and $76 \%$ respectively. Control diet was fed without the plants' supplementation. Hematology and histology of fish kidney were observed after fish received three-week feed treatments. The results showed that there was an increase of erythrocyte levels in the treated fish groups fed with diet-one and diet-two
\end{abstract}

\footnotetext{
\# Korespondensi: Balai Riset Perikanan Budidaya Air Tawar dan

Penyuluhan Perikanan.

Il. Sempur No. 1, Bogor 16154, Indonesia.

Tel. + 622518313200

E-mail: nunak.nafigoh@kkp.go.id
} 


\begin{abstract}
compared with the control $(0.4 \pm 0.14)$. However, no significant differences of erythrocyte level were observed between fish groups fed with diet -one and die-two $(1.5 \pm 0.17$ and $1.4 \pm 0.1)$. Leucocyte levels also increased in the treated fish group with diet-one and diet-two compared to the control ( $10.5 \pm 0.46)$. However, there was no significant difference of leucocyte level between the fish group feed with diet-one and diet-two (15.1 \pm 1.19 and $17.6 \pm 1.14)$. Histological observations found that there were more hematopoietic tissues in the fish kidney of proliferated treated group than the control group. However, therewas no effect on hemoglobin level and leukocyte percentage differentiation between the treatment and control groups. This study concludes that medicinal herbs as enrichment ingredients in fish diet can increase the health quality of fish.
\end{abstract}

KEYWORDS: health status; Clarias gariepinus; supplemented feed; Piper betler leaf; Psidium guajava leaf; Tithonia diversifolia leaf

\section{PENDAHULUAN}

Pembudiaya telah lama memberikan tanaman obat pada ikan peliharaannya untuk pencegahan penyakit sekaligus sebagai pengobatan (Wahjuningrum et al., 2014). Biasanya pembudidaya menggunakan tanaman yang tumbuh di sekitar kolam untuk melakukan tindakan pencegahan ataupun pengobatan. Salah satu tanaman perdu yang banyak tumbuh di sekitar kolam adalah kipahit (Tithonia diversifolia). Suhaya (2014) menemukan bahwa kipahit adalah salah satu tanaman yang mempunyai potensi untuk dikembangkan menjadi salah satu sumber tanaman obat. Sedangkan penggunaan daun sirih (Piper betle) dan jambu biji (Psidium guajava) telah diteliti oleh Angka (2005), dan melaporkan bahwa daun sirih dan jambu biji mampu mengatasi penyakit bakterial Aeromonas hydrophila. Tanaman obat yang menarik perhatian adalah daun sirih, dikarenakan sirih merupakan tanaman yang diketahui mengandung antibiotik alami yang cukup tinggi. Dengan demikian tanaman ini menarik untuk dijadikan kandidat potensial pengganti antibiotik sintetis, bahkan daun sirih mempunyai aktivitas antibakteri terhadap Staphylococcus aureus dan Enterococcus yang telah resistan terhadap methicilin dan vancomycin (Valle et al., 2016).

Gambaran darah merupakan parameter yang dapat dipercaya sebagai representasi status kesehatan ikan yang diamati. Parameter ini menyajikan data yang cukup akurat namun sederhana. Gambaran darah mampu menyajikan status fisiologi ikan, baik dipengaruhi oleh proses di dalam tubuh ikan maupun dari lingkungan hidup ikan yang diamati. Parameter yang penting selain gambaran darah adalah pengamatan organ penghasil darah di mana terdapat jaringan hematopoietik di dalamnya sebagai tempat di mana darah diproduksi, berproliferasi, dan berdiferensiasi (Ivanc et al., 2016).

Penggunaan daun sirih, kipahit, dan jambu biji tersebut sebagai bahan penanggulangan penyakit bakterial pada ikan telah dipelajari sebelumnya. Namun belum pernah dilakukan studi penggunaan kombinasi dari ketiga tanaman obat tersebut. Pengaruh pemberian tanaman obat sebagai pencegahan perlu dilakukan untuk menghindari serangan agen penyakit pada ikan dengan meningkatkan status kesehatan pada ikan yang dipelihara. Dalam penelitian ini dilakukan pengamatan pada perubahan gambaran darah sebagai parameter status kesehatan dari ikan lele yang menerima suplementasi kombinasi daun sirih, jambu, dan kipahit dalam pakan, serta histologi dari organ ginjal sebagai salah satu organ yang terkait dengan sistem produksi darah termasuk yang berkaitan dengan pertahanan tubuh bagi ikan. Penelitian ini bertujuan untuk mengetahui status kesehatan ikan lele (C. gariepinus) yang menerima pakan dengan suplemen tanaman obat kombinasi dari daun sirih, jambu biji, dan kipahit melalui pengamatan gambaran darah dan histologi ginjal sebagai organ produsen darah.

\section{BAHAN DAN METODE}

\section{Serbuk Tanaman Obat}

Tanaman obat diperoleh dari kebun yang berlokasi di Ciampea, Bogor, Jawa Barat. Pemanenan daun tanaman yang digunakan sebagai obat mengikuti pedoman pemanenan untuk pembuatan simplisia (Depkes RI, 1985). Daun sirih, jambu biji, dan kipahit yang dipetik merupakan daun kelima dari pucuk, sehingga daun yang diambil merupakan daun yang telah membuka sempurna. Daun kemudian dipotong, dicuci, dan dikeringanginkan selama 15 menit. Potongan daun kemudian dijemur di bawah sinar matahari selama delapan jam, dan dilanjutkan dengan dikeringanginkan selama lima hari. Setelah itu, daun dimasukkan dalam mesin penggiling untuk dijadikan serbuk dan dikemas dalam wadah bersih dan kering.

\section{Persiapan Pakan Perlakuan}

Pakan yang digunakan merupakan pakan komersial (pelet) dengan kadar protein 31\%33\% yang telah melalui proses penepungan. Dua kombinasi dari tanaman obat dipersiapkan, yaitu kombinasi-1 terdiri dari daun sirih, jambu biji, dan kipahit dalam persentase yang sama (33\%33\%33\% dan kombinasi-2 dengan perbandingan 5\%19\%76\% Sebanyak 80 gram 
campuran daun tanaman obat diaduk bersama $1 \mathrm{~kg}$ tepung dari pakan komesial (pelet). Pada campuran ini juga ditambahkan 1\%carboxymethylcellulose (CMC) sebagai pengikat. Selanjutnya adonan ini dicetak kembali menjadi pelet.

\section{Pemeliharaan Ikan dan Pengambilan Sampel}

Ikan ditransportasikan dari Kecamatan Cijeruk Kabupaten Bogor untuk dipelihara di Instalasi Riset Pengendalian Penyakit Ikan, Depok. Ukuran ikan lele yang dipilih adalah 7-8 cm dengan bobot 3-4 g. Transportasi ikan menggunakan kantong plastik yang telah disuplai dengan oksigen. Ikan diberikan makanan komersial dengan kadar protein 31\%33\% selama proses adaptasi pada lingkungan laboratorium. Sebanyak 20 ekor ikan lele dipelihara dalam air sebanyak 20 liter menggunakan wadah plastik berukuran $53 \mathrm{~cm} \times 45 \mathrm{~cm} \times 25 \mathrm{~cm}$. Pakan perlakuan diberikan selama tiga minggu, sebanyak dua kali dalam sehari. Bobot pakan yang diberikan adalah $5 \%$ dari biomassa ikan. Percobaan dilakukan dengan rancangan acak lengkap dalam tiga ulangan pada setiap perlakuan dan kontrol.

Sampel darah diambil pada akhir pemeliharaan dari vena caudal dengan syringe $1 \mathrm{~mL}$. Darah dimasukkan ke dalam tube dengan 3,8\% Na-sitrat sebagai antikoagulan. Untuk analisis diferensial leukosit, darah diteteskan ke atas kaca objek dan diratakan.

\section{Hematokrit}

Penentuan nilai hematokrit dilakukan menggunakan tabung hematokrit. Darah dimasukkan ke dalam tabung hingga penuh, kemudian disentrifugasi menggunakan sentrifus hematokrit selama 20 menit. Persentase sel darah yang memadat (packed cell volume) dari total keseluruhan darah dihitung sebagai nilai hematokrit dan dinyatakan dalam persen (Sirimanapong et al., 2014).

\section{Hemoglobin}

Nilai hemoglobin ditentukan menggunakan metode sianmethemoglobin (Misra et al., 2006). Sebanyak $5 \mathrm{~mL}$ larutan Drapkin dimasukkan dalam tabung, kemudian ditambahkan $20 \mu \mathrm{L}$ darah. Larutan kemudian diinkubasi selama 2-3 menit dan diukur nilai absorbansinya menggunakan spektrofotometer pada panjang gelombang $540 \mathrm{~nm}$. Hasil nilai optical density (OD) dikalikan dengan nilai standar $\operatorname{HiCN}(36,8)$.

\section{Sel Darah Merah, Sel Darah Putih, dan Deferensiasi Leukosit}

Penghitungan jumlah sel darah merah dan putih mengikuti metode Binaii et al. (2014). Untuk menghitung sel darah merah; darah diencerkan dalam larutan Dacie's (3 g trisodium citrate (Merck); $1 \mathrm{~mL}$ formalin (Merck); dan $99 \mathrm{~mL}$ akuades). Sedangkan untuk menghitung sel darah putih; darah diencerkan dalam larutan Turk's (1 mL crystal violet 1\%(Merck); $0,5 \mathrm{~mL}$ asam asetat glasial (Merck); $100 \mathrm{~mL}$ akuades). Penghitungan sel darah merah dan darah putih mengikuti rumus:

$$
\text { Sel darah merah }(\mathrm{SDM})=\mathrm{N} \times \mathrm{p} \times 50
$$

di mana:

$N$ : jumlah SDM dalam lima kotak (bilik R)

$P$ : pengenceran

50 : volume kotak (4.000)/jumlah bujur sangkar (80)

$$
\text { Sel darah putih }(\mathrm{SDP})=\mathrm{N} \times \mathrm{p} \times 2,5
$$

di mana:

$N$ : jumlah SDP dalam empat kotak (bilik W)

$P$ : pengenceran

2,5: volume kotak (160)/jumlah bujur sangkar (64)

Persentase diferensial leukosit diamati dengan menghitung 100 sel darah putih dan diamati secara deskriptif untuk masing-masing jumlah dari tiap jenis leukosit (Corrêa et al., 2017).

\section{Histologi}

Pada akhir percobaan, satu ekor ikan dari setiap bak dibedah dan organ ginjalnya diambil dan difiksasi dalam 10\% NBF (neutral buffered formalin). Jaringan kemudian didehidrasi menggunakan rapid tissue processor (Milestone) mengikuti petunjuk dari alat yang digunakan. Selengkapnya, jaringan dimasukkan dalam histomodule dan difiksasi menggunakan formalin selama 30 menit. Jaringan kemudian didehidrasi dalam etanol absolut (Merck) selama 25 menit, dilanjutkan dengan isopropanol (Merck) selama 55 menit dan terakhir dimasukkan dalam parafin selama satu jam 15 menit. Jaringan yang telah didehidrasi ditambahkan parafin (Merck) dalam proses blocking. Blok yang sudah selesai diolah, dipotong menggunakan mikrotom dengan ketebalan $4 \mu \mathrm{m}$. Potongan jaringan diletakkan pada kaca preparat dan diwarnai menggunakan metode Hematoksilin (Merck) dan Eosin (Merck). Pengamatan jaringan dilakukan menggunakan mikroskop (olympus BX 41) dengan perbesaran 400 kali.

\section{Analisis Statistik}

Semua data hematologi dianalisis secara ANOVA satu arah menggunakan program statitistik SPSS versi 18. Hasil histologi dianalisis secara deskriptif. 


\section{HASIL DAN BAHASAN}

Tanaman mengandung beberapa bahan aktif yang mungkin dapat memengaruhi proses biokomia dalam tubuh. Studi fitokimia tanaman obat telah banyak dilakukan. Senyawa yang terkandung dalam tanaman obat di antaranya alkaloid, flavonoid, steroid, terpenoid, tannin, dan saponin. Beberapa tanaman juga mengandung karbohidrat, asam amino, dan vitamin (Oluwasola \& Dairo, 2016). Ketiga tanaman obat yang digunakan pada percobaan ini mempunyai kandungan bahan aktif seperti tertera pada Tabel 1.

Pada analisis senyawa aktif ditemukan bahwa senyawa yang terkandung dalam daun sirih di antaranya adalah chavibetol dan eugenol (Shah et al., 2016). Sedangkan daun jambu dan kipahit mempunyai kandungan senyawa aktif yang hampir sama termasuk di dalamnya pinene dan Germacrene D dalam presentase yang berbeda (Thenmozhi \& Rajan, 2015).

Gambaran darah pada ikan dipengaruhi oleh beragam faktor, antara lain; adanya penyakit, proses inflamasi, stres, fisiologi, asupan nutrisi, serta faktor lingkungan (Clauss et al., 2008). Nutrisi ikan yang telah ditambah bubuk daun tanaman obat mengandung bahan aktif diduga mampu memberikan dampak pada perubahan status kesehatan pada ikan.
Hasil analisis hematokrit dan hemoglobin menunjukkan tidak ada perbedaan yang signifikan antara perlakuan dan kontrol. Jumlah sel darah merah pada perlakuan penambahan daun tanaman obat menunjukkan perbedaan yang nyata secara statistik dibandingkan dengan kontrol. Jumlah sel darah putih pada kelompok kombinasi-2 $(17,6 \pm 1,14)$ menunjukkan perbedaan signifikan secara statistik dibandingkan kontrol (10,5 \pm 046), namun perlakuan kombinasi satu $(15,1 \pm 1,19)$ menunjukkan perbedaan yang tidak signifikan dibandingkan pada kelompok kombinasi-2 dan kontrol (Tabel 2).

Flavonoid yang terkandung pada ketiga tanaman obat yang digunakan diduga memberikan pengaruh pada status kesehatan ikan yang diamati. Flavonoid merupakan metabolit sekunder yang diproduksi oleh tanaman, dibagi dalam beberapa grup termasuk flavonol, flavone, isoflavone, flavanones, flavanols, dan anthocyanidins. Flavonoid dapat bertindak sebagai anti-inflamasi dan antioksidan, serta mempunyai peranan dalam sistem imun (Perez-Cano \& Castell, 2016).

Tannin merupakan senyawa yang bersifat antinutrisi jika dikonsumsi secara terus-menerus, terutama mengganggu penyerapan besi dari asupan nutrisi. Senyawa ini terdeteksi cukup banyak pada daun sirih

Tabel 1. Kandungan senyawa bahan aktif pada daun sirih (Piper betler leaf), jambu biji (Psidium guajava leaf), dan kipahit (Tithonia diversifolia leaf)

Table 1. Active compound of Piper betler leaf, Psidium guajava leaf, and Tithonia diversifolia leafers

\begin{tabular}{|c|c|c|c|c|}
\hline $\begin{array}{l}\text { Senyawa bahan aktif } \\
\text { Active compound }\end{array}$ & $\begin{array}{l}\text { Daun sirih } \\
\text { Piper betle }\end{array}$ & $\begin{array}{l}\text { Daun jambu biji } \\
\text { Psidium guajava }\end{array}$ & $\begin{array}{c}\text { Daun kipahit } \\
\text { Tithonia diversifolia }\end{array}$ & $\begin{array}{l}\text { Manfaat } \\
\text { Benefits }\end{array}$ \\
\hline $\begin{array}{l}\text { Flavonoid } \\
\text { Flavonoid }\end{array}$ & $46.08 \mathrm{mg} \cdot \mathrm{g}^{-1}$ & $6.42 \mathrm{mg} \cdot \mathrm{g}^{-1}$ & $0.85 \mathrm{mg} \cdot \mathrm{g}^{-1}$ & $\begin{array}{l}\text { Antioksidan } \\
\text { Antioxidants }\end{array}$ \\
\hline $\begin{array}{l}\text { Fenolik } \\
\text { Phenolic }\end{array}$ & $47.48 \mathrm{mg} \cdot \mathrm{g}^{-1}$ & $9.33 \mathrm{mg} \cdot \mathrm{g}^{-1}$ & $0.06 \mathrm{mg} \cdot \mathrm{g}^{-1}$ & $\begin{array}{l}\text { Antioksidan } \\
\text { Antioxidants }\end{array}$ \\
\hline $\begin{array}{l}\text { Alkaloid } \\
\text { Alkaloid }\end{array}$ & - & + nd & $15.35 \mathrm{mg} \cdot \mathrm{g}^{-1}$ & $\begin{array}{l}\text { Antioksidan } \\
\text { Antioxidants }\end{array}$ \\
\hline $\begin{array}{l}\text { Terpenoid } \\
\text { Terpenoid }\end{array}$ & $+\mathrm{nd}$ & + nd & $0.13 \mathrm{mg} \cdot \mathrm{g}^{-1}$ & $\begin{array}{l}\text { Anti kanker } \\
\text { Anti cancer }\end{array}$ \\
\hline $\begin{array}{l}\text { Tannin } \\
\text { Tannin }\end{array}$ & $29.33 \mathrm{mg} \cdot \mathrm{g}^{-1}$ & $4.3 \mathrm{mg} \cdot \mathrm{g}^{-1}$ & $0.54 \mathrm{mg} \cdot \mathrm{g}^{-1}$ & $\begin{array}{l}\text { Haemostatik } \\
\text { Haemostatic }\end{array}$ \\
\hline $\begin{array}{l}\text { Saponin } \\
\text { Saponin }\end{array}$ & $+n d$ & $3.67 \mathrm{mg} \cdot \mathrm{g}^{-1}$ & $0.76 \mathrm{mg} \cdot \mathrm{g}^{-1}$ & $\begin{array}{l}\text { Antimikrobial } \\
\text { Antimicrobial }\end{array}$ \\
\hline
\end{tabular}

$\begin{array}{lcc}\text { Acuan } & \text { Periyanayagam et al . (2012) } & \text { Kenneth et al . (2017) } \\ \text { Reference } & \text { Sundang et al . (2012) } & \text { Thenmozhi \& Rajan (2015) }\end{array}$

Keterangan (Note): - $\quad$ : tidak terdeteksi (not detected);

+ nd : terdeteksi namun tidak diamati secara kuantitatif (detected but not quantitively observed) 
Tabel 2. Gambaran darah ikan lele (Clarias gariepinus) setelah menerima pakan bersuplemen tanaman obat kombinasi

Table 2. Hematological parameter of Clarias gariepinus after received medicinal plant-enriched diet (mean $\pm \mathrm{SE}$ )

\begin{tabular}{lccc}
\hline \multirow{2}{*}{$\begin{array}{c}\text { Parameter } \\
\text { Parameters }\end{array}$} & \multicolumn{3}{c}{ Perlakuan (Treatments) } \\
\cline { 2 - 4 } & $\begin{array}{c}\text { Kombinasi-1 } \\
\text { Combination-1 }\end{array}$ & $\begin{array}{c}\text { Kombinasi-2 } \\
\text { Combination-2 }\end{array}$ & $\begin{array}{c}\text { Kontrol } \\
\text { Control }\end{array}$ \\
\hline Hematokrit (Hematocrite) $(\%)$ & $28.9 \pm 1.77^{\mathrm{a}}$ & $28.9 \pm 1.61^{\mathrm{a}}$ & $32.5 \pm 1.05^{\mathrm{a}}$ \\
Hemoglobin (Hemoglobin $)\left(\mathrm{g} \cdot \mathrm{dL}^{-1}\right)$ & $2.8 \pm 0.07^{\mathrm{a}}$ & $4.1 \pm 0.25^{\mathrm{a}}$ & $3.0 \pm 0.25^{\mathrm{a}}$ \\
Jumlah sel darah merah (Erythrocyte) $\left(10^{6} \cdot \mathrm{mm}^{-3}\right)$ & $1.5 \pm 0.17^{\mathrm{a}}$ & $1.4 \pm 0.1^{\mathrm{a}}$ & $0.4 \pm 0.14^{\mathrm{b}}$ \\
Jumlah sel darah putih (Leucocyte) $\left(10^{5} \cdot \mathrm{mm}^{-3}\right)$ & $15.1 \pm 1.19^{\mathrm{ab}}$ & $17.6 \pm 1.14^{\mathrm{a}}$ & $10.5 \pm 0.46^{\mathrm{b}}$ \\
\hline
\end{tabular}

Keterangan (Note): Perbedaan huruf pada baris yang sama mengindikasikan beda nyata secara statistik $(P<0,05)$; (mean $\pm S E, n=3$ )

Different letter in one row indicate a statistically significant different $(P<0.05)$, (mean $\pm S E, n=3))$

(Tabel 1). Perlakuan kombinasi satu yang mengandung $33 \%$ daun sirih dimungkinkan memengaruhi nilai gambaran darah pada ikan uji. Sedangkan pada perlakuan kombinasi-2, jumlah daun sirih yang ditambahkan sejumlah 5\% Daun kipahit merupakan tanaman obat dengan persentase tertinggi $(76 \%)$ pada pelakuan kombinasi-2. Kandungan senyawa tannin pada daun kipahit hanya $0,54 \%$ jauh lebih rendah dibandingkan dengan kandungan tannin pada daun sirih. Pada studi yang melibatkan tannin pada pakan benih Laboe rohita oleh Prusty et al. (2007) menyebutkan bahwa penambahan tannin pada pakan hingga $20 \mathrm{~g} \mathrm{~kg}^{-1}$ pakan tidak memengaruhi pertumbuhan namun berdampak pada gambaran darah dari ikan yang diuji. Sedangkan konsumsi tannin yang masih terkandung dalam daun teh memberikan dampak pada penurunan penyerapan besi jika dibandingkan hewan uji tikus yang tidak mendapatkan perlakuan (Delimont et al., 2012). Pada ikan diduga terjadi juga respons yang sama saat ikan menerima pakan yang ditambah daun yang mengandung tannin.

Pada penelitian sebelumnya penambahan bagian aerial dari tanaman willow pada pakan ikan mas mampu meningkatkan produksi sel darah putih namun tidak memengaruhi nilai hematokrit dan hemoglobin serta jumlah sel darah merah pada kelompok perlakuan dibandingkan kontrol. Kandungan flavonoid, tannin dan steroid yang tinggi pada tanaman willow diduga meningkatkan sifat antibakteri tanaman tersebut (Pakravan et al., 2012), namun diduga pula senyawa tersebut memengaruhi proses biokimia dalam tubuh ikan yang diberikan perlakuan.

Secara umum sel darah putih ikan terdiri atas monosit, neutrophil, dan limfosit. Monosit dan neutrofil merupakan sel darah putih yang bisa bertindak sebagai makrofag. Sedangkan sel darah limfosit akan berdiferensiasi menjadi sel T dan sel B. Pada perlakuan baik kombinasi satu maupun dua tidak terdapat perbedaan pada komposisi leukosit yang terhitung jika dibandingkan dengan kelompok kontrol (Gambar 1). Hasil ini disebabkan perubahan persentase jenis leukosit lebih banyak dipengaruhi oleh adanya aktivitas serangan patogen atau perubahan kondisi lingkungan terhadap ikan budidaya, seperti hasil studi yang telah dilaporkan Irang \& Reyes (2017) dengan menambahkan ekstrak acacia, annatto, dan indian mango pada media pemeliharaan ikan nila.

Pada teleostei organ utama yang memproduksi sel darah adalah ginjal. Struktur ginjal depan tidak berhubungan dengan fungsi ekskresi. Pada ginjal depan ini didominasi oleh sel yang berhubungan dengan jaringan hematopoietik (Gambar 2). Sel blast sebagai bagian dari sel hemopoietik berada dalam jaringan stroma yang berfungsi sama dengan sumsum tulang belakang pada mamalia. Selain berfungsi sebagai produsen sel darah, jaringan hematopoietic juga berfungsi sebagai pusat melanomakrofag sebagai sel yang berkaitan dengan sistem pertahanan pada ikan teleostei (Genten et al., 2009). Jaringan hematopietik yang disuplementasi dengan tanaman obat (Gambar 2a; 2b) tampak berproliferasi lebih baik dibandingkan dengan kontrol (Gambar 2c).

Differensiasi sel darah terjadi pula di organ ginjal depan. Eritrosit berbentuk elips atau bulat, limfoid mempunyai nukleus besar dengan sitoplasma tipis di sekitar nukleus. Neutrofil biasanya mempunyai bentuk nukleus yang terdiri atas dua lobus dengan sito plasma yang ber-granul, sedangkan monosit mempunyai 


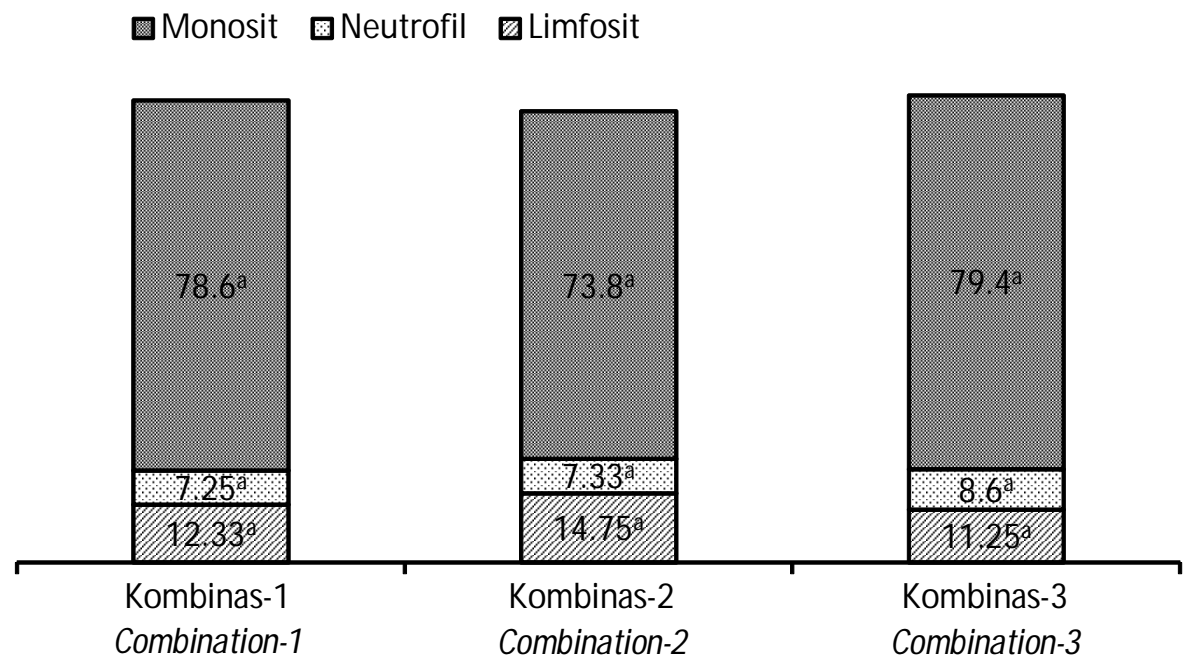

Gambar 1. Leukosit diferensiasi pada ikan lele (Clarias gariepinus) setelah menerima pakan bersuplemen tanaman obat kombinasi (mean $\pm \mathrm{SE}$ ). Perbedaan huruf mengindikasikan beda nyata secara statistik $(P<0,05)$.

Figure 1. Differential leucocyte of Clarias gariepinus after received medicinal plant-enriched diet (mean \pm SE). Diffrent letter indicate a statistically significant different $(P<0.05)$.

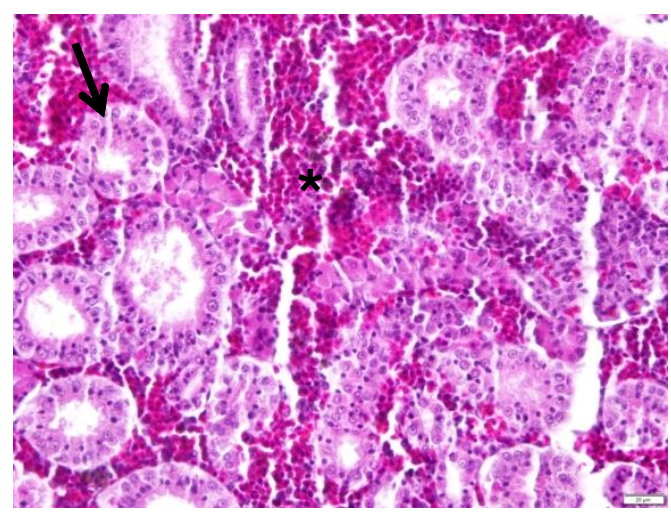

A

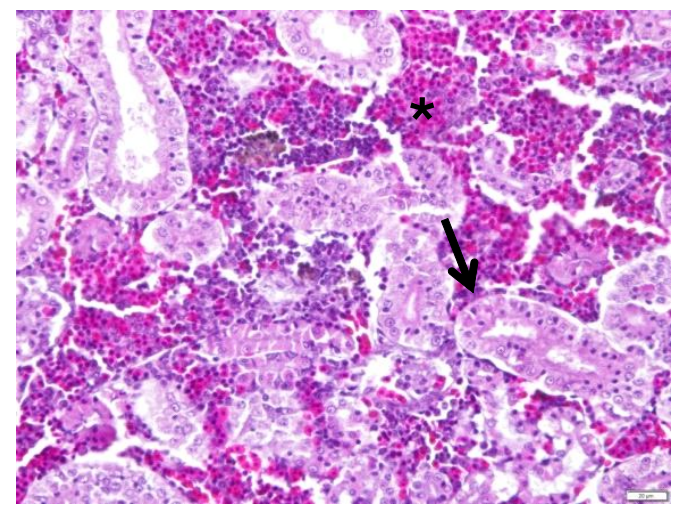

B

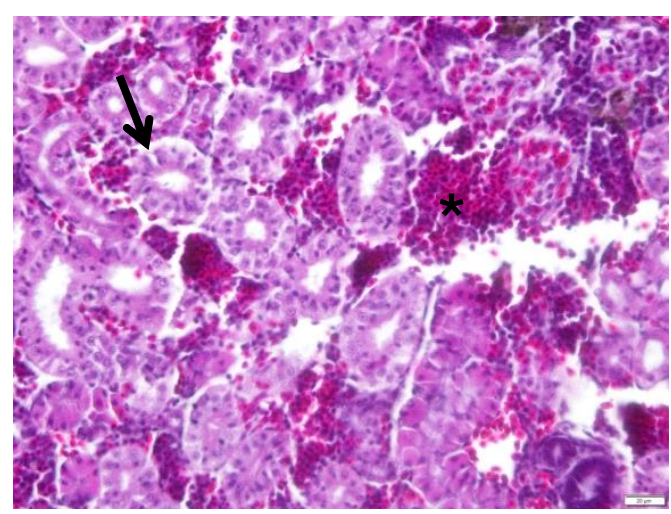

C

Gambar 2. Histologi organ ginjal ikan lele (Clarias gariepinus) setelah menerima pakan bersuplemen tanaman obat kombinasi; (a) kombinasi-1; (b) kombinasi-2; (c) kontrol. Jaringan tubulus (tanda panah), area ekstensif dari jaringan hemopoetic (*).

Figure 2. Kidney histology of Clarias gariepinus after received medicinal plant-enriched diet (a) combination-1; (b) combination-2; (c) control, kidney's tubules (arrows), extensive area of hematopoietic (*). 
bentuk sel yang tidak beraturan dengan nukleus berukuran besar (Gangopadhyay \& Homechaudhur, 2011).

Dalam ginjal, pembentukan sel darah diawali dari sel punca hematopoietik (hematopoietic stem cell) yang berasal dari sel punca multiponent. Sel punca ini berproliferasi dan berdiferensiasi terus-menerus dalam organ. Sel punca hematopoietik berdiferensiasi menjadi sel hematopoietikmyeloid dan limphatic. Myeloid berdiferensiasi menjadi sel eritopoiesis, trombopoiesis, eosinofil, basofil, granulopoiesis, dan monopoiesis. Sel-sel tersebut akan bermaturasi menjadi eritrosit, trombosit, eosinofil, basofil, neutrofil, dan monosit. Lymphoid berdiferensiasi menjadi sel NK, limfopoiesis $T$, dan limfopoiesis $B$ yang akan matang menjadi sel NK, limfosit $T$, dan $B$ (Theml et al., 2004). Sel eritrosit, limfosit, monosit, dan neutrofil hasil maturasi dari sel hematopoietik myeloid disajikan pada Gambar 3.

Pada kelompok perlakuan, peningkatan jumlah sel darah yang terhitung diduga disebabkan adanya metabolit sekunder bahan tanaman yang berupa senyawa aktif. Kedua kombinasi proporsi daun tanaman obat mempunyai kandungan bahan yang sama dengan persentase yang berbeda. Ketiganya mengandung eugenol dari tanaman sirih dan terpe- nes, baik pinene maupun caryophyllene yang berasal dari daun jambu dan kipahit. Pada kombinasi-1, ketiga tanaman obat dikombinasikan dengan perbandingan yang sama, sedangkan pada kombinasi dua jumlah tanaman obat yang mengandung terpenes memiliki persentase lebih banyak. Persentase yang berbeda dari kedua kombinasi tersebut menghasilkan pengaruh yang tidak berbeda nyata pada parameter-parameter yang diamati.

Seperti telah dijelaskan sebelumnya bahwa sel darah terbentuk dari sel punca multiponent yang berdiferensiasi. Sel punca multiponent ini mampu memperbaharui diri sendiri dalam kurun waktu tertentu. Perbaruan sel punca ini dipengaruhi oleh kondisi lingkungan mikro dalam jaringan organ. Penelitian melibatkan penambahan senyawa aktif eugenol pada kondisi in vitro mampu meningkatkan proliferasi dan migrasi pada sel punca mesenchyma yang diisolasi dari sumsum tulang belakang (Sisakhtnezhad et al., 2017). Hasil penelitian ini diduga mempunyai mekanisme yang sama pada sel punca hematopoietic yang berimbas pada naiknya jumlah sel darah merah dan darah putih pada kelompok ikan yang diberi pakan perlakuan.

Proliferasi dan diferensiasi sel punca juga dipengaruhi oleh reseptor cannabinoid yakni CBI dan

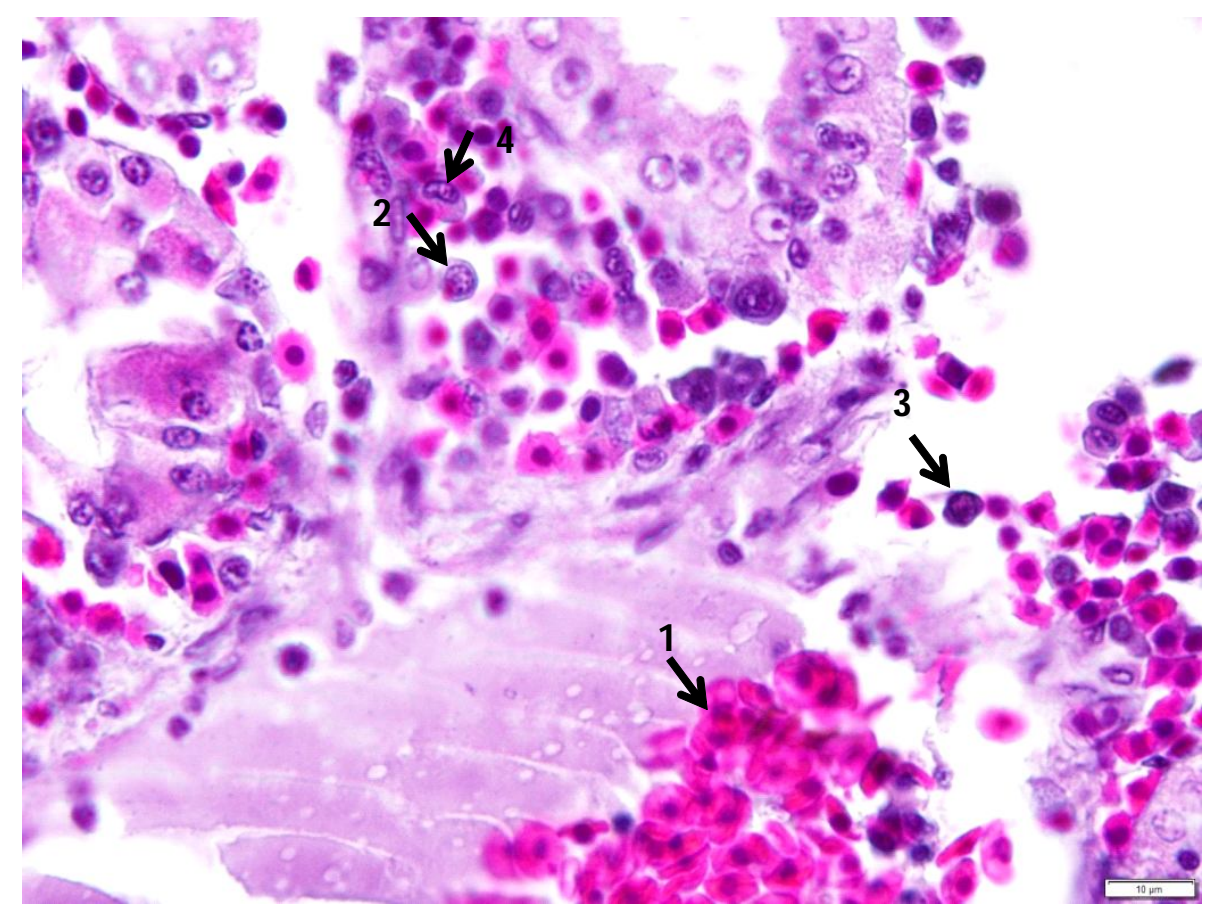

Gambar 3. Histologi organ ginjal ikan lele (Clarias gariepinus) berdasarkan differensiasi sel darah (1) eritrosit; (2) limfosit; (3) monosit; (4) neutrofil.

Figure 3. Kidney histology of Clarias gariepinus based on blood cell differentiation (1) erytrocyte; (2) limphocyte; (3) monocyte; (4) neutrophil. 
CB2 (Galve-Roperh et al., 2013). Reseptor ini terletak di beberapa bagian tubuh terutama di otak (Mackie, 2008). Reseptor canabinoid bersama dengan ligan membentuk sistem endocannabinoid (endocannabinoid system) yang dimodulasi oleh senyawa yang terdapat pada tanaman darat dan air termasuk terpena (terpenoid) yang terkandung pada tanaman obat kipahit dan jambu biji (Badal et al., 2017).

\section{KESIMPULAN}

Perlakuan penambahan tanaman obat kombinasi satu dan dua pada pakan dapat meningkatkan status kesehatan ikan lele. Hal ini terlihat dari produksi sel darah merah yang meningkat hingga 3,6 kali dan produksi sel darah putih yang meningkat hingga 1,55 kali jika dibandingkan dengan kelompok kontrol. Hasil pengamatan histologi menunjukkan bahwa tanaman obat baik kombinasi-1 maupun kombinasi-2 yang telah diberikan mampu meningkatkan proliferasi organ hematopoietik.

\section{UCAPAN TERIMA KASIH}

Penulis mengucapkan terima kasih pada Saudara Ahmad Wahyudi, Edi Farid Wadjdi, Setiadi, dan Johan Afandi, serta seluruh staf Instalasi Riset Pengendalian Penyakit Ikan, Balai Riset Perikanan Air Tawar dan Penyuluhan Perikanan, Bogor atas bantuanya pada saat proses pengerjaan penelitian.

\section{DAFTAR ACUAN}

Angka, S.L. (2005). Kajian penyakit M AS pada ikan lele dumbo patologi, pencegahan dan pengobatan dengan fitofarmaka. Disertasi. Institut Pertanian Bogor. Indonesia.

Badal, S., Smith, K.N., \& Rajnarayanan, R. (2017). Analysis of natural product regulation of cannabinoid receptors in the treatment of human disease. Pharmacology \& Therapeutics, 180, 24-48.

Binaii, M., Ghiasi, M., Farabi, S.M.V., Pourgholam, R., Fazli, H., Safari, R., Alavi, S,E., Taghavi, M.J., \& Bankehsaz, Z. (2014). Biochemical and hematoimmunological parameters in juvenile beluga (Huso huso) following the diet supplemented with nettle (Urtica dioica). Fish \& Shellfish Immunology, 36, 4651.

Clauss, T.M., Dove, A.D.M., \& Arnold, J.E. (2008). Hematologic disorders of fish. Veterinary Clinics of North America - Exotic Animal Practice, 11(3), 445462.

Corrêa, S.A.S., Abessa, D.M.S., Santos, L.G., Silva, E.B., \& Seriani, R. (2017). Differential blood counting in fish as a non-destructive biomarker of water contamination exposure. Toxicological and Environmental Chemistry, 99(3), 482-491.
Delimont, N.M., Haub, M.D., \& Lindshield, B.L. (2012). The impact of tannin consumption on iron bioavailability and status/: A narrative review. Current Developments In Nutrition, p. 1-12.

Departemen Kesehatan Republik Indonesia. (1985). Cara pembuatan simplisia. Direktorat Jenderal Pengawasan Obat dan Makanan

Gangopadhyay, K. \& Homechaudhur, S. (2011). Descriptive characteristics of haemopoietic cell lineages in a facultative air breathing fish Clarias batrachus (L.). Turkish Journal of Zoology, 35(5), 737-746.

Genten, F., Terwinghe, E., \& Danguy, A. (2009). Atlas of fish histology. Second eds. New Hampshire, USA: Science Publishers.

Irang, E.Y.F. \& Reyes, A.T. (2017). Assessment of the inhibitory effect of selected medicinal plants against Aeromonas Sobria in nile tilapia (Oreochromis niloticus L.). International Journal of Agricultural Technology, 13, 2229-2248.

Ivanc, A., Haskovic, E., Jeremic, S., \& Dekic, R. (2016). Hematological evaluation of welfare and health of fish. Praxis Veterinaria, 53(3), 191-202.

Kenneth, E., Paul, T., Istifanus, N., Uba, U., Rejoice, A., Victor, O., \& Mohammed, S. (2017). Phytochemical analysis and antibacterial activity of Psidium guajava L leaf extracts. GSC Biological and Pharmaceutical Sciences, 1(2), 13-19.

Mackie, K. (2008). Cannabinoid receptors: where they are and what they do. Journal of Neuroendocrinology, 20(s1), 10-14.

Misra, S., Sahu, N.P., Pa, A.K., Xavier, B., Kumar, S., \& Mukherjee, S.C. (2006). Pre- and post-challenge immuno-haematological changes in Labeo rohita juveniles fed gelatinised or non-gelatinised carbohydrate with n-3 PUFA. Fish \& Shellfish Immunology, 21, 346-356.

Olayinka, B.U., Raiyemo, D.A., \& Etejere, E.O. (2015). Phytochemical and proximate compostition of Tithonia diversifoila (Hemsl.) A. Gray. Annals, Food Science and Technology, 16(1), 195-200.

Oluwasola, T.A. \& Dairo, F.A.S. (2016). Proximate composition, amino acid profile and some anti-nutrients of Tithonia diversifolia cut at two different times. African Journal of Agricultural Research, 11(38), 3659-3663.

Pakravan, S., Hajimoradloo, A., \& Ghorbani, R. (2012). Effect of dietary willow herb, Epilobium hirsutum extract on growth performance, body composition, haematological parameters and Aeromonas hydrophila challenge on common carp, Cyprinus carpio. Aquaculture Research, 43(6), 861-869.

Perez-Cano, F.jJ. \& Castell, M. (2016). Flavonoids, inflammation and immune system. Nutrients, 8(659), 8-11. 
Periyanayagam, K., Jagadeesan, M., Kavimani, S., \& Vetriselvan, T. (2012). Pharmacognostical and phyto-physicochemical profile of the leaves of Piper betle L. var Pachaikodi (Piperaceae) - valuable assessment of its quality. Asian Pacific Journal of Tropical Biomedicine, 2(2 SUPPL.), 5-9.

Prusty, A.K., Sahu, N.P., Pal, A.K., Reddy, A.K., \& Kumar, S. (2007). Effect of dietary tannin on growth and haemato-immunological parameters of Labeo rohita (Hamilton) fingerling. Animal Feed Science and Technology, 136: 96-108.

Shah, S.K., Garg, G., Jhade, D., \& Patel, N. (2016). Piper betle: Phytochemical, pharmacological and nutritional value in health management. International Journal of Pharma Sciences, Revision and Research, 38(2), 181-189.

Sirimanapong, W., Thompson, K.D., Kledmanee, K., Thaijongrak, P., Collet, B., Lin, E., \& Adams, A. (2014). Optimisation and standardisation of functional immune assays for striped cat fish (Pangasianodon hypophthalmus) to compare their immune response to live and heat killed Aeromonas hydrophila as models of infection and vaccination. Fish and Shellfish Immunology, 40(2), 374-383.

Sisakhtnezhad, S., Heidari, M., \& Bidmeshkipour, A. (2017). Eugenol enhances proliferation and migration of mouse bone marrow-derived mesenchymal stem cells in vitro. Environmental Toxicology and Pharmacology, 57, 166-174. https://doi.org/10.1016/ j.etap.2017.12.012.
Suhaya, D.D. (2014). efektivitas ekstrak kipahit tithonia diversifolia dan kirinyuh eupatorium inulaefolium untuk pencegahan dan pengobatan penyakit akibat infeksi Aeromonas hydrophila pada ikan lele Clarias sp. melalui pakan. Skripsi. Institut Pertanian Bogor. Indonesia

Sundang, M., Nasir, C.S., Sipaut, S.N.S., \& Othman, H. (2012). Antioxidant activity, phenolic, flavonoid and tannin content of Piper betle and Leucosykecapitella murni. Malaysian Journal of Fundamental \& Applied Sciences, 8(1), 1-6.

Theml, H., Diem, H., \& Haferlach, T. (2004). Color atlas of hematology/ : Practical microscopic and clinical diagnosis. ( ${ }^{\text {nd }}$ eds). Thieme, Stuttgart. Germany.

Thenmozhi, S. \& Rajan, S. (2015). GC-MS analysis of bioactive compounds in Psidium guajava leaves. Journal of Pharmacognosy and Phytochemistry, 3(5), 162-166.

Valle, D.L., Cabrera, E.C., Puzon, J.J.M., \& Rivera, W.L. (2016). Antimicrobial activities of methanol, ethanol and supercritical CO2 extracts of Philippine Piper betle L. on clinical isolates of gram positive and gram negative bacteria with transferable multiple drug resistance. PLOS ONE, 11(1), 1-14.

Wahjuningrum, D., Astrini, R., \& Setiawati, M. (2014). Pencegahan infeksi Aeromonas hydrophila pada benih ikan lele Clarias sp. yang berumur 11 hari menggunakan bawang putih Allium sativum dan meniran Phyllanthus niruri. Jurnal Akuakultur Indonesia, 12(1), 94-104. 